\title{
Melanoma-Associated Antigen 4
}

National Cancer Institute

\section{Source}

National Cancer Institute. Melanoma-Associated Antigen 4. NCI Thesaurus. Code

C104515.

Melanoma-associated antigen 4 (317 aa, $\sim 35 \mathrm{kDa}$ ) is encoded by the human MAGEA4 gene. This protein may be involved in embryonal development, tumor transformation, or tumor progression. 